\title{
Uzdatnianie sprężonego powietrza w pojazdach trakcyjnych
}

\begin{abstract}
$W$ artykule omówiono zagadnienie uzdatniania sprężonego powietrza w pojazdach trakcyjnych, ze szczególnym uwzględnieniem jego osuszania. Zwrócono uwagę na zagrożenia, jakie powoduje obecność pary wodnej w urzqdzeniach i instalacjach pneumatycznych. Omówiono klasyfikację czystości sprężonego powietrza w odniesieniu do pojazdów trakcyjnych. Opisano zjawisko adsorpcji oraz przedstawiono budowę sorbentów, stanowiacych główny element osuszaczy adsorpcyjnych. Omówiono budowę $i$ zasady działania osuszaczy adsorpcyjnych $i$ membranowych.
\end{abstract}

\section{Wstęp}

Postęp techniczny w projektowaniu i eksploatacji pojazdów trakcyjnych powoduje rezygnację ze stosowania sprężonego powietrza do napędu urządzeń pomocniczych $w$ pojazdach i zastępowanie go energia elektryczna, np. wycieraczki, syreny czy drzwi.

Są jednak urządzenia i układy, w których sprężone powietrze jest konieczne np.: w układach hamulcowych pojazdów trakcyjnych.

Specyfika pracy pojazdów szynowych powoduje znaczne utrudnienia $\mathrm{w}$ procesie wytwarzania i uzdatniania sprężonego powietrza. Do najistotniejszych utrudnień należą:

- szeroki zakres temperatury otoczenia $\mathrm{w}$ eksploatacji (od $-25^{\circ} \mathrm{C}$ do $\left.+45^{\circ} \mathrm{C}\right)$

- zmienna i znacznie zróżnicowana wilgotność powietrza

- duże zapylenie powietrza

- drgania od toru podczas jazdy oddziaływujące na agregat sprężarkowy

- konieczność ograniczania gabarytów agregatu.

Stawia to przed producentami sprężarek poważne zadania, aby nie było zakłóceń procesu wytwarzania sprężonego powietrza, zapewniając jednocześnie wymaganą jego jakość, głównie poziomu zapylenia, zawilgocenia i zaolejenia. Substancje stałe zanieczyszczające powietrze usuwa się za pomocą różnego rodzaju filtrów, zależnie od wymaganej czystości.

Powietrze atmosferyczne pobierane do sprężania $\mathrm{w}$ agregacie sprężarkowym zawsze zawiera, oprócz zanieczyszczeń substancjami stałymi, parę wodną powodująca zawilgocenie powietrza. Natomiast sprężone powietrze, opuszczające agregat sprężarkowy, zawiera minimalne ilości pary olejowej i znacznie więcej pary wodnej. W wyniku chłodzenia w chłodnicy następuje skraplanie pary i koalescencja (łączenie się małych kropli w większe wskutek wzajemnych zderzeń).

Zawarty w sprężonym powietrzu kondensat olejowo-wodny jest najgroźniejszym i najmniej pożądanym czynnikiem. Uzdatnianie sprężonego powietrza musi prowadzić do usunięcia tego kondensatu.

$\mathrm{W}$ artykule omówiono działania, jakie podejmuje się $\mathrm{w}$ procesie uzdatniania sprężonego powietrza $\mathrm{w}$ pojazdach trakcyjnych, szczególnie w zakresie usuwania wilgotności i stosowanych do tego celu urządzeń (najczęściej: cyklony, filtry i osuszacze). Jednym z rodzajów osuszaczy, które znalazły zastosowanie w pojazdach trakcyjnych, są osuszacze adsorpcyjne, w których następuje wiązanie pary wodnej $\mathrm{z}$ powietrza na powierzchni ciała stałego. Jest to proces odwracalny. Regeneracja osuszacza umożliwia jego długotrwałe używanie, bez jakichkolwiek czynności obsługowych, co jest niewątpliwą zaletą tego typu osuszaczy.

\section{Uzdatnianie sprężonego powietrza}

\subsection{Klasyfikacja czystości powietrza}

Podstawowymi zanieczyszczeniami sprężonego powietrza są: ciała stałe (pyły), woda i olej. Tych właśnie zanieczyszczeń, a dokładniej ich stężenia w powietrzu, dotyczy klasa czystości powietrza.

Przez wiele lat klasę czystości sprężonego powietrza określano w oparciu o normę PN-ISO 85731:1995 [3], ale w wyniku uwag zgłaszanych przez użytkowników podczas przeglądów i uzgodnień w Komitecie Technicznym ISO TC 118 wprowadzono do określania czystości powietrza normę międzynarodową ISO 8573-1:2001 (popr. 1:2002) [5], co spowodowało zgłoszenie normy z 1995r. do wycofania. Metody badań ilości poszczególnych zanieczyszczeń, pozwalające określić czystość powietrza wg [5], opisano w normach [4,6,7,8,9,10,11 i 12$]$.

Klasa czystości sprężonego powietrza jest to umowne oznaczenie cyfrowe, zawierające informacje o stężeniu trzech głównych rodzajów zanieczyszczeń: ciał stałych, wody i oleju w sprężonym powietrzu.

\section{- Zanieczyszczenia ciałami stałymi (zapyle- nie)}

Ciała stałe w postaci pyłu są wchłaniane przez sprężarkę wraz z zasysanym powietrzem, mimo stosowania filtrów wlotowych. Ilość ich jest często powiększona o zużywające się elementy sprężarki i jej 
instalacji.

Do usuwania (oddzielania) zanieczyszczeń ciałami stałymi stosuje się różnego rodzaju filtry. W określaniu rodzaju filtrów i efektywności filtracji (usuwania zanieczyszczeń) stosuje się pojęcie cząstki rozumianej jako niewielki, pojedynczy element substancji stałej lub ciekłej.

Filtry dobiera się w zależności od wymagań czystości powietrza pozbawionego cząstek o określonej wielkości i określa się zdolnością oddzielania czasstek o zadanej wielkości. I tak np. do usuwania cząstek o wymiarze ok. $5 \mu \mathrm{m}$ i większych można stosować ziarnowe filtry porowate (tworzywo porowate, ceramika, spiekany metal), o wymiarze $1 \mu \mathrm{m}$ filtry włókninowe typu głębokiego, a o wymiarze $0,01 \mu \mathrm{m}$ submikronowe włókninowe filtry koalescencyjne.

Parametrem wyrażającym cechę filtra może być efektywność odfiltrowania, penetracja i współczynnik filtracji.

Efektywność odfiltrowania to różnica stężeń zanieczyszczeń przed i za filtrem, podzielona przez stężenie zanieczyszczeń przed filtrem.

Penetracja to stosunek stężenia cząstek za filtrem do stężenia przed filtrem.

Współczynnik filtracji określa stosunek liczby cząstek stałych (danej wielkości) zatrzymanych na filtrze, do liczby takich cząstek, które przeszły przez przegrodę filtracyjną.

Klasy zanieczyszczeń powietrza substancjami stałymi (stanowiące pierwszy parametr opisujący klasy czystości powietrza) określa się dla cząstek stałych o wielkości do $5 \mu \mathrm{m}$ stężeniem w postaci liczby cząstek na $\mathrm{m}^{3}$ (klasy $1 \div 5$ ), a dla wielkości cząstek powyżej 5 $\mu \mathrm{m}$ jako stężenie masowe $\mathrm{w} \mathrm{mg} / \mathrm{m}^{3}$ (klasy 6 i 7). Klasy zanieczyszczeń $\mathrm{w}$ postaci cząstek stałych przedstawiono w tabeli 1 .

Uściślenia wymaga także stosowanie jednostek pomiarowych. W opisach aparatury czy układów pneumatycznych zaleca się stosowanie jednostek SI. Jednakże używane są również inne jednostki nie należące do SI, a uznane przez ISO. I tak ciśnienie można określać w barach (bar) - (1 bar=10 Pa), objętość w litrach (1) - (1 $\left.1=10^{-3} \mathrm{~m}^{3}\right)$, a czas w minutach (min.) i godzinach (h).

- Zawartość wody w sprężonym powietrzu

Powietrze atmosferyczne pobierane do sprężania zawsze zawiera parę wodna. $\mathrm{W}$ procesie sprężania następuje wzrost temperatury, a następnie schłodzenie (w chłodnicy), co powoduje wykroplenie wody, natomiast powietrze $\mathrm{w}$ dalszym ciągu pozostaje nasycone parą wodną.

Wilgoć w sprężonym powietrzu jest zjawiskiem bardzo niekorzystnym i stąd niepożądanym, głównie z uwagi na możliwość powodowania korozji instalacji i urządzeń. Toteż zagadnieniu zmniejszania (usuwania) wilgoci poświęca się dużo uwagi.

Zawartość wody w powietrzu określa się dwoma terminami: zawilgoceniem i zawodnieniem.

Klasy zawilgocenia określa się za pomocą ciśnieniowego punktu rosy. Punkt rosy to temperatura, w której rozpoczyna się skraplanie pary wodnej. Ciśnieniowy punkt rosy to punkt rosy przy określonym ciśnieniu sprężonego powietrza.

Istnieje ponadto $\mathrm{w}$ terminologii pojęcie atmosferycznego punktu rosy odniesione do punktu rosy w warunkach ciśnienia atmosferycznego. Ten termin nie może być stosowany do opisu zawartości wody w sprężonym powietrzu.

Zawilgocenie, charakteryzowane ciśnieniowym punktem rosy, opisuje klasy zawilgocenia $1 \div 6$. Zawodnienie opisane jest jako masowe stężenie wody $\mathrm{w}$ postaci cieczy w $\mathrm{g} / \mathrm{m}^{3}$ (klasy $7 \div 9$ ). W oparciu o obowiązującą normę [5], klasy zawilgocenia przedstawiono w tabeli 2, a klasy zawodnienia w tabeli 3 .

Klasy zawilgocenia [5]

Tabela 2

\begin{tabular}{|c|c|}
\hline Klasa & Punkt rosy $\left[{ }^{\circ} \mathrm{C}\right]$ \\
\hline 0 & $\begin{array}{c}\text { W przypadkach szczególnych } \\
\text { wymagań, po uzgodnieniu }\end{array}$ \\
\hline 1 & $\leq-70$ \\
\hline 2 & $\leq-40$ \\
\hline 3 & $\leq-20$ \\
\hline 4 & $\leq+3$ \\
\hline 5 & $\leq+7$ \\
\hline 6 & $\leq+10$ \\
\hline
\end{tabular}

Tabela 1

\begin{tabular}{|c|c|c|c|c|c|c|}
\hline \multirow{3}{*}{ Klasa } & \multicolumn{4}{|c|}{ Największa liczba cząstek w $1 \mathrm{~m}^{3}$} & \multirow{3}{*}{$\begin{array}{c}\text { Wielkość } \\
\text { cząstek }[\mu \mathrm{m}]\end{array}$} & \multirow{3}{*}{$\begin{array}{l}\text { Stężenie } \\
{\left[\mathrm{mg} / \mathrm{m}^{3}\right]}\end{array}$} \\
\hline & \multicolumn{4}{|c|}{ Rozmiar cząstki $d[\mu \mathrm{m}]$} & & \\
\hline & $\leq 0,1$ & $0,1<d \leq 0,5$ & $0,5<d \leq 1,0$ & $1,0<d \leq 5,0$ & & \\
\hline 0 & \multicolumn{4}{|c|}{ W przypadkach szczególnych wymagań, po uzgodnieniu } & \multirow{6}{*}{-} & \multirow{6}{*}{-} \\
\hline 1 & Nie określa się & 100 & 1 & 0 & & \\
\hline 2 & , & 100000 & 1000 & 10 & & \\
\hline 3 & , & Nie określa się & 10000 & 500 & & \\
\hline 4 & , & , & Nie określa się & 1000 & & \\
\hline 5 & , & , & , & 20000 & & \\
\hline 6 & \multicolumn{4}{|c|}{-} & $\leq 5$ & $\leq 5$ \\
\hline 7 & \multicolumn{4}{|c|}{-} & $\leq 40$ & $\leq 10$ \\
\hline
\end{tabular}


Klasy zawodnienia [5] Tabela 3

\begin{tabular}{|c|c|}
\hline Klasa & $\begin{array}{c}\text { Stężenie wody w postaci cieczy } \\
C_{w}\left[\mathrm{~g} / \mathrm{m}^{3}\right]\end{array}$ \\
\hline 7 & $C_{w} \leq 0,5$ \\
\hline 8 & $0,5<C_{w} \leq 5$ \\
\hline 9 & $5<C_{w} \leq 10$ \\
\hline
\end{tabular}

Skroploną parę wodną usuwa się ze sprężonego powietrza jako kondensat w separatorze, natomiast wilgotność w osuszaczu.

\section{- Zanieczyszczenie powietrza olejem (zaole-} jenie)

Proces sprężania powietrza $\mathrm{w}$ sprężarkach śrubowych polega na sprężaniu mieszaniny zassanego powietrza atmosferycznego $\mathrm{z}$ wtryskiwanym na ssaniu olejem. Zadaniem oleju jest uszczelnienie przestrzeni między wirującymi śrubami, a także odebranie ciepła wydzielanego $\mathrm{w}$ procesie sprężania. Po sprężeniu następuje oddzielenie oleju od powietrza, co zazwyczaj przebiega dwuetapowo: w komorze wstępnego oddzielania i w oddzielaczu oleju. Prawidłowo działający układ oddzielania oleju sprawia, że w sprężonym powietrzu opuszczającym sprężarkę, resztkowa zawartość oleju jest niewielka.

Cząstki oleju, w postaci mgły i aerozoli, zawarte $\mathrm{w}$ sprężonym powietrzu opuszczającym chłodnicę, zostają zwykle usunięte w separatorze, razem ze skroploną para wodną, tworząc kondensat wodno-olejowy (o charakterystycznym mlecznym zabarwieniu). Po przejściu przez filtr cyklonowy i oddzieleniu kondensatu wodno-olejowego, zawartość sumaryczna oleju w sprężonym powietrzu nie przekracza $3 \mathrm{mg} / \mathrm{m}^{3}$.

Taki poziom stężenia oleju $\mathrm{w}$ sprężonym powietrzu w większości instalacji przemysłowych (także w instalacji pojazdów trakcyjnych) jest zadowalający. Natomiast cząstki oleju wpływają zdecydowanie negatywnie na dalszy proces uzdatniania powietrza, jeżeli w układzie znajduje się osuszacz adsorpcyjny. Powietrze nawet $\mathrm{z}$ niewielką zawartością oleju przechodząc przez osuszacz adsorpcyjny zmniejsza jego skuteczność, aż do całkowitego pozbawienia właściwości adsorpcyjnych sorbentu zanieczyszczonego olejem.

To sprawia, że w układzie uzdatniania powietrza z wykorzystaniem osuszacza, zabudowuje się przed nim zwykle dwa filtry: zgrubny i dokładny. Zakładając wlotowe sumaryczne stężenie oleju w sprężonym powietrzu na poziomie $3 \mathrm{mg} / \mathrm{m}^{3}$, po przejściu przez filtr zgrubny resztkowa zawartość oleju wyniesie 0,1 $\mathrm{mg} / \mathrm{m}^{3}$, a po przejściu przez filtr dokładny 0,01 $\mathrm{mg} / \mathrm{m}^{3}$.

Pary oleju też zostają usunięte przez filtry, jeżeli maksymalne sumaryczne stężenie oleju na wlocie nie zostanie przekroczone. Stężenie par w sprężarkach śrubowych zależy głównie od temperatury, jaką osiąga mieszanina powietrzno-olejowa $\mathrm{w}$ procesie sprężania. Przy prawidłowo zaprojektowanym i działającym układzie chłodzenia, sumaryczny poziom zaolejenia łącznie $\mathrm{z}$ aerozolami na wyjściu z separatora nie powinien przekraczać $3 \mathrm{mg} / \mathrm{m}^{3}$.

Sprężone powietrze o uzyskanym masowym stężeniu oleju $0,01 \mathrm{mg} / \mathrm{m}^{3}$ jest dla wszystkich rozwiązań technicznych (oprócz przemysłu spożywczego, farmacji i celów medycznych) w pełni zadowalające. Jeżeli zaistnieje uzasadniona potrzeba całkowitego usunięcia par oleju, można to uzyskać za pomocą np. drobnocząstkowego węgla aktywnego na podłożu z tkaniny, albo bez podłoża np. po uformowaniu go i spieczeniu w kształcie walca filtracyjnego.

Klasy sumarycznego zaolejenia powietrza podane w normie ISO 8573-1:2001 przestawiono w tabeli 4. Należy jednak zwrócić uwagę, że stężenie to odnosi się do ciśnienia absolutnego 1 bar, zatem dla sprężonego powietrza będzie odpowiednio większe.

Klasy zaolejenia sumarycznego [5]

Tabela 4

\begin{tabular}{|c|c|}
\hline Klasa & $\begin{array}{c}\text { Stężenie sumaryczne oleju } \\
{\left[\mathrm{mg} / \mathrm{m}^{3}\right]}\end{array}$ \\
\hline 0 & $\begin{array}{c}\text { W przypadkach szczególnych } \\
\text { wymagań, po uzgodnieniu }\end{array}$ \\
\hline 1 & $\leq 0,01$ \\
\hline 2 & $\leq 0,1$ \\
\hline 3 & $\leq 1$ \\
\hline 4 & $\leq 5$ \\
\hline
\end{tabular}

\subsection{Układy uzdatniania powietrza}

Powietrze to mieszanina wielu gazów, głównie azotu i tlenu, zanieczyszczona cząstkami stałymi. Zanieczyszczenia (ich rodzaj, wielkość) zmieniają się w zależności od środowiska. Kolejnym składnikiem powietrza jest para wodna, występująca w zmiennych ilościach (tzw. wilgotność powietrza).

Zanieczyszczenia te, występujące w sposób naturalny w powietrzu, są wchłaniane (mimo stosowania filtrów wlotowych) z powietrzem do sprężania. W procesie sprężania zmniejszenie objętości powietrza powoduje zagęszczenie zanieczyszczeń, ponadto rosnąca temperatura a następnie schłodzenie powoduje wydzielanie się kondensatu wodno-olejowego o szczególnie szkodliwym, korodującym działaniu.

Sprężone powietrze, w zależności od zastosowania, musi posiadać nie tylko wymagane ciśnienie i określone natężenie przepływu, ale także jakość. Ta jakość to pozbawienie powietrza zanieczyszczeń stałych, wody i oleju. Czystość powietrza musi być dostosowana do celu i parametrów urządzeń z jakimi współpracuje.

Oczyszczanie powietrza ze wspomnianych zanieczyszczeń przeprowadza się w układach uzdatniania powietrza, którego przykład przedstawiono na rys. 1 . 


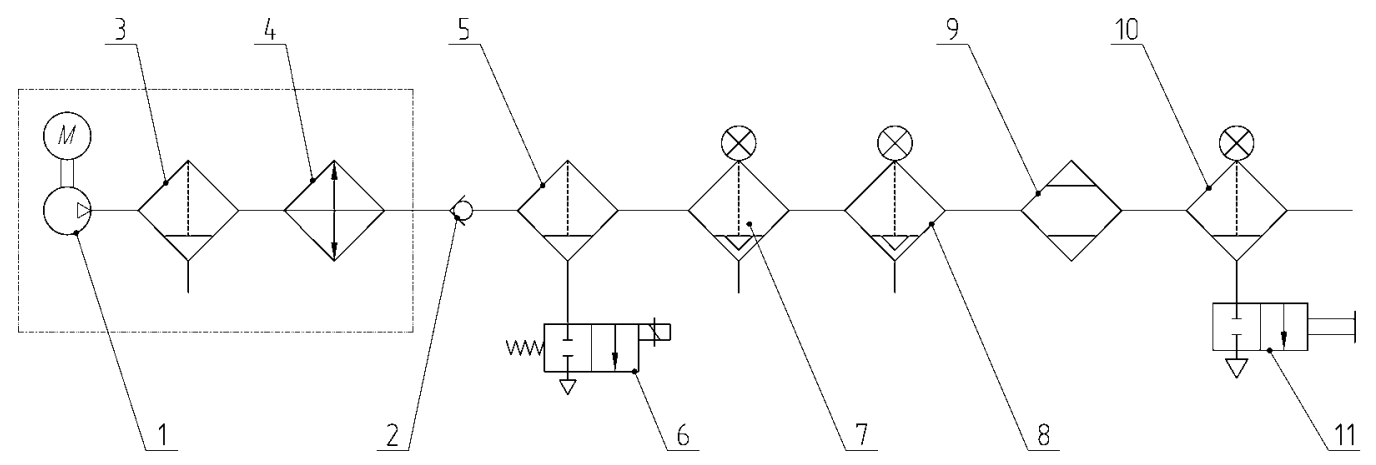

Rys. 1. Przykładowy schemat układu uzdatniania sprężonego powietrza z osuszaczem adsorpcyjnym

1 - Sprężarka śrubowa, 2 - Zawór zwrotny, 3 - Filtr z układem oddzielania oleju, 4 - Chłodnica, 5 - Separator cyklonowy, 6

- Zawór elektropneumatyczny, 7 - Filtr zgrubny z zaworem spustowym, 8 - Filtr dokładny z zaworem spustowym, 9 - Adsorpcyjny osuszacz powietrza, 10 - Filtr pyłowy, 11 - Zawór spustowy.

Sprężenie powietrza następuje w sprężarce 1, z której po oddzieleniu oleju i schłodzeniu w chłodnicy 4 przepływa przez separator cyklonowy $\mathbf{5}$, pokazany na rys. 2. Dzięki specjalnie ukształtowanym kanałom wlotowym i wewnętrznym kierownicom, strumień powietrza zostaje rozdzielony na kilka strumieni, które wprawione $\mathrm{w}$ ruch wirowy powodują odrzucanie skroplonej pary wodnej (i ewentualnie drobin oleju) na ścianki separatora i gromadzą się w dolnej części korpusu. Powietrze natomiast przepływa kanałami wylotowymi dalej, pozbawione już znacznej części kondensatu wodno-olejowego.

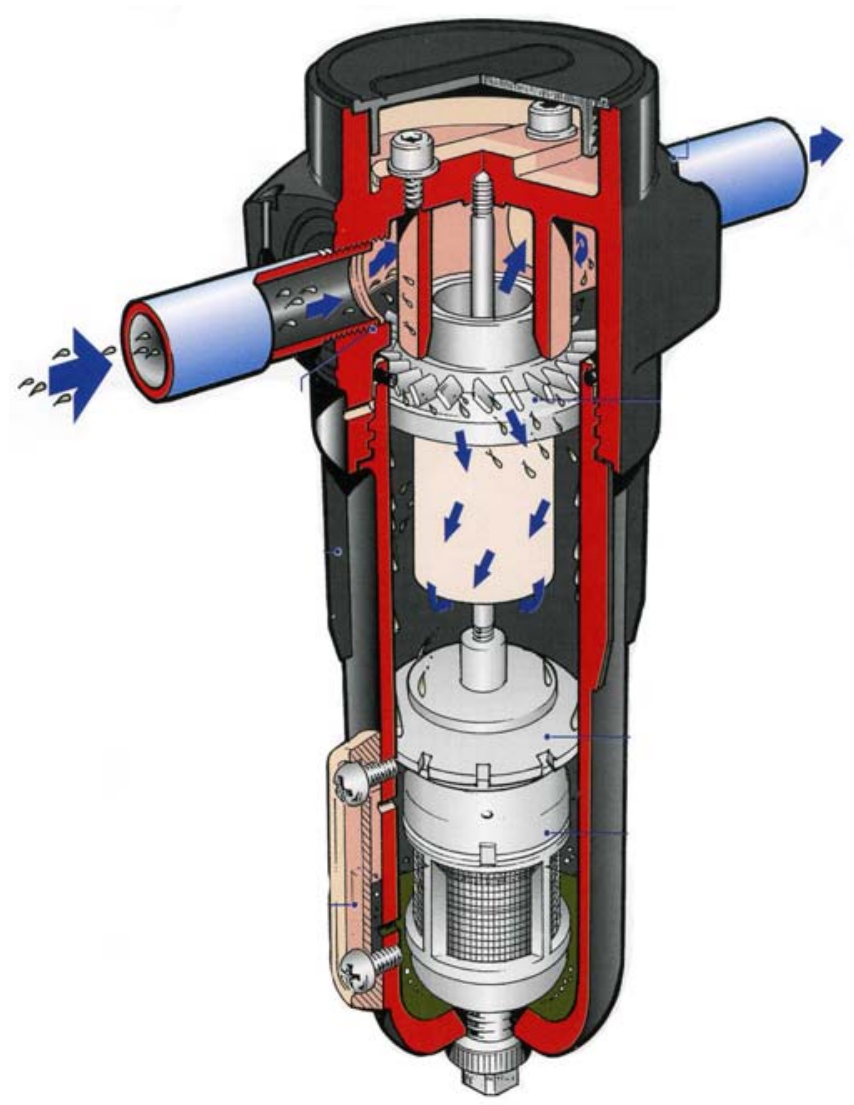

Rys. 2. Separator cyklonowy [13]
Zgromadzony w separatorze kondensat jest usuwany automatycznie, poprzez zawór $\mathbf{6}$ sterowany elektrycznie, $\mathrm{z}$ nastawieniem czasu spustu jak i przerw między kolejnymi spustami.

Dalszym etapem oczyszczania sprężonego powietrza są filtry. Zazwyczaj stosuje się dwa filtry: zgrubny 7 i dokładny 8 . Filtry są zaopatrzone w ręczny lub automatyczny zawór spustowy pozwalający na okresowe usuwanie zanieczyszczeń. Ogólnie rzecz ujmując, filtry oczyszczają powietrze $\mathrm{z}$ zanieczyszczeń substancjami stałymi i resztkowej ilości oleju. Należy zwrócić uwagę, że olej zawarty w powietrzu zmniejsza efektywność osuszania, dlatego stosowanie odpowiednich filtrów jest tak bardzo istotne.

Po przejściu przez filtry powietrze dochodzi do osuszacza 9, a stamtąd poprzez filtr 10 do instalacji. Budowę i działanie osuszacza omówiono w rozdziale 4, natomiast filtr przeciwpyłowy $\mathbf{1 0}$ służy do usunięcia z powietrza ewentualnych drobin sorbentu ,zabranych" z osuszacza. Filtr ten zazwyczaj posiada ręczny zawór spustowy 11.

\subsection{Czystość sprężonego powietrza $w$ pojazdach trakcyjnych}

Sprężone powietrze $\mathrm{w}$ większości pojazdów trakcyjnych wytwarzane jest przez sprężarki śrubowe. Dotyczy to głównie pojazdów nowych, produkowanych jak i modernizowanych, na których zastępuje się sprężarki tłokowe śrubowymi.

Poziom czystości (klasę czystości) sprężonego powietrza, dostarczanego do instalacji pneumatycznej pojazdu, narzucają sterowane i uruchamiane tym powietrzem układy i urządzenia.

\section{- Zapylenie}

W sprężarkach śrubowych pył, który zawsze jest wchłaniany z powietrzem przez sprężarkę mimo stosowania na wlocie filtrów, łączy się z olejem, który wraz z powietrzem tworzy mieszaninę sprężaną. Proces sprężania powoduje znaczny wzrost temperatury tej mieszaniny. Po sprężeniu a następnie oddzieleniu oleju od powietrza, cząstki stałe znajdują się w oleju 
do czasu jego przejścia przez filtr oleju. Zatem powietrze opuszczające sprężarkę pozbawione jest większych cząsteczek pyłu. $\mathrm{Z}$ dużym prawdopodobieństwem można określić klasę zanieczyszczenia substancjami stałymi tego powietrza jako $2 \mathrm{wg}$ [5].

Jeżeli w układzie uzdatniania powietrza zainstalowany jest osuszacz adsorpcyjny, to na wyjściu z niego montuje się filtr przeciwpyłowy, usuwający ewentualne cząstki adsorbentu zabrane przez osuszane powietrze.

Pył jaki spotyka się w instalacji pneumatycznej, szczególnie pojazdów modernizowanych, może pochodzić z zanieczyszczeń przewodów, ich korozji czy procesu zużywania się elementów układu. Aby uchronić aparaturę pneumatyczną przed zanieczyszczeniem, w każdym przypadku stosuje się w pobliżu tych urządzeń filtry dobrane pod kątem wymagań w zakresie dopuszczalnych zanieczyszczeń (zapylenia).

\section{- Zawodnienie}

Schłodzenie sprężonego powietrza w chłodnicy powoduje, że para wodna zawarta $\mathrm{w}$ tym powietrzu zostaje wytrącona i w postaci kropel może być usunięta w separatorze cyklonowym.

Tak oczyszczone powietrze nie jest jednak pozbawione całkowicie pary wodnej, a szkodliwość jej wpływu na instalację i urządzenia jest oczywista. Stąd też coraz częściej w układach uzdatniania sprężonego powietrza w pojazdach trakcyjnych stosuje się osuszacze. Klasa zawodnienia sprężonego powietrza po przejściu przez osuszacz może osiagnąć poziom $2 \mathrm{wg}$ [5].

\section{- Zaolejenie}

Niewielkie cząstki oleju w postaci kropel i aerozoli zostają usunięte ze sprężonego powietrza $\mathrm{w}$ postaci kondensatu wodno-olejowego w separatorze cyklonowym. Przy długotrwałej pracy sprężarki w warunkach mniejszej intensywności chłodzenia (np. w wysokiej temperaturze otoczenia), w wychodzącym ze sprężarki powietrzu może znajdować się para olejowa.

Niewielkie ilości pary olejowej, które mogą się dostać do instalacji pneumatycznej, nie mają negatywnego wpływu na pracę urządzeń i aparatury, a nawet stanowią ochronę przeciwkorozyjną metalowych przewodów (rur) instalacji w pojeździe. Poziom zaolejenia sprężonego powietrza staje się problemem $\mathrm{w}$ przypadku zastosowania $\mathrm{w}$ układzie osuszacza (szczególnie adsorpcyjnego). Nawet niewielkie ilości oleju w powietrzu przechodzącym przez osuszacz zmniejszają właściwości adsorpcyjne sorbentu, stąd konieczność usuwania oleju w celu ochrony osuszacza, który ostatecznie usuwa $\mathrm{z}$ powietrza wilgoć. W celu usunięcia par oleju stosuje się zazwyczaj dwa filtry zabudowane przed osuszaczem. Po przejściu przez te filtry sprężone powietrze uzyskuje zwykle 1 lub 2 klase zaolejenia sumarycznego wg [5]. Natomiast $\mathrm{w}$ układach pozbawionych filtrów i osuszaczy, klasę zaolejenia powietrza dostarczanego do instalacji można określić na 3 lub 4.

Reasumując: poprawnie zaprojektowany i sprawnie działający układ uzdatniania sprężonego powietrza $\mathrm{w}$ pojeździe trakcyjnym wyposażonym $\mathrm{w}$ separator cyklonowy, zestaw filtrów i osuszacz może osiagnąć klasę czystości sprężonego powietrza 2(3), 2, 1(2), gdzie poszczególne cyfry oznaczają kolejno: klasę zanieczyszczenia substancjami stałymi, klasę zawodnienia i klasę zaolejenia sumarycznego.

\section{Zjawisko adsorpcji pary wodnej}

\subsection{Adsorpcja fazy gazowej na powierzchniach cial stałych}

Zjawisko polega na gromadzeniu się gazu (tu: pary wodnej) na powierzchni ciała stałego.

Adsorpcja ma charakter powierzchniowy, czym różni się od absorpcji polegającej na pochłanianiu w całej objętości. Substancja gromadząca się na powierzchni to adsorbat, zaś przyjmująca to adsorbent.

Proces wiązania substancji gazowej na powierzchni substancji stałej może mieć charakter chemiczny (chemisorpcja) lub fizyczny.

Adsorpcja fizyczna to efekt przyciagania sił Van der Waalsa. Cząsteczki na powierzchni ciała stałego mają tylko częściowo wysycone siły przyciagania międzycząsteczkowego. W rezultacie, adsorbent (ciało stałe) na swojej powierzchni adsorbuje cząsteczki adsorbatu (pary wodnej).

Większa powierzchnia przekłada się na większą ilość substancji gromadzonej przez adsorbent. W procesie wiązania nie uczestniczy jednak cała powierzchnia adsorbentu, lecz tylko pewne jej obszary tzw. centra aktywne: pęknięcia, pory, kanaliki. W miejscach tych stosunkowo słabe siły międzycząsteczkowe nakładaja się na siebie, dając wypadkową odpowiedzialną za wiązanie adsorbatu.

Przykładowo, struktura kanalikowa węgla aktywnego sprzyja nie tylko rozwinięciu powierzchni, lecz także znacznemu wzrostowi powierzchniowej gęstości centrów aktywnych; powierzchnia rzeczywista $1 \mathrm{~g}$ węgla aktywnego wynosi ok. $500 \mathrm{~m}^{2}$.

Jeżeli siły wiążące adsorbat na powierzchni adsorbentu mają naturę wiązania chemicznego (tzn. są realizowane $\mathrm{z}$ udziałem elektronów), to występuje adsorpcja chemiczna (chemisorpcja). Centrami aktywnymi są różne wypukłości, krawędzie, naroża itd., gdzie znajdujące się atomy, cząsteczki lub jony nie mają w pełni wysyconych wiązań.

Chemisorpcja nie jest jednak reakcją chemiczną. Zaadsorbowana cząsteczka w zasadzie zachowuje swoja tożsamość. Ulega jedynie pewnym naprężeniom, co osłabia w niej wiązania i zwiększa jej reaktywność (obniża barierę energetyczną reakcji).

$\mathrm{W}$ tabeli 5 przedstawiono istotne różnice $\mathrm{w}$ charakterze fizycznym i chemicznym adsorpcji. 
Charakterystyka adsorpcji fizycznej i chemicznej [2]

Tabela 5

\begin{tabular}{|c|c|}
\hline Adsorpcja fizyczna & Chemisorpcja \\
\hline \multicolumn{2}{|c|}{ Efekty cieplne } \\
\hline Około $40 \mathrm{~kJ} / \mathrm{mol}$ adsorbatu & $\begin{array}{c}\text { Około } 400 \mathrm{~kJ} / \mathrm{mol} \\
\text { adsorbatu }\end{array}$ \\
\hline \multicolumn{2}{|c|}{ Bariera energetyczna } \\
\hline $\begin{array}{l}\text { Niska - proces przebiega sto- } \\
\text { sunkowo szybko nawet } \mathrm{w} \text { ni- } \\
\text { skich temperaturach }\end{array}$ & $\begin{array}{l}\text { Wysoka - proces przebiega } \\
\text { z obserwowalną szybkością } \\
\text { w wyższych temperaturach }\end{array}$ \\
\hline \multicolumn{2}{|c|}{ Liczba warstw adsorbatu } \\
\hline Jedna lub kilka warstw & Tylko jedna warstwa \\
\hline \multicolumn{2}{|c|}{ Rodzaj sit powodujacych adsorpcję } \\
\hline $\begin{array}{l}\text { Przyciaganie międzycząstecz- } \\
\text { kowe }\end{array}$ & $\begin{array}{l}\text { Zbliżone do wiązania che- } \\
\text { micznego }\end{array}$ \\
\hline
\end{tabular}

Z uwagi na charakter adsorpcji wykorzystywanej w osuszaczach powietrza dalsze rozważania dotyczą adsorpcji fizycznej.

Ruch cząstek już zaadsorbowanych na powierzchni adsorbenta warunkowany jest wielkością energii kinetycznej tychże cząstek. Jeżeli bariera potencjału pomiędzy sąsiednimi miejscami jest duża, w porównaniu $\mathrm{z}$ energią kinetyczną zaadsorbowanych cząsteczek, to występuje adsorpcja zlokalizowana (brak migracji cząstek). Gdy ta bariera jest znacznie mniejsza, wówczas przeważa charakter mobilny i cząsteczki poruszają się dość swobodnie po powierzchni. Niezależnie od ruchów w płaszczyźnie powierzchni, cały czas zachodzą procesy adsorpcji na powierzchni i desorpcji już zaadsorbowanych cząsteczek.

Zjawisko charakteryzuje wielkość adsorpcji, czyli ilości zaadsorbowanego adsorbatu. W rzeczywistości mierzalną wielkością jest tzw. nadmiar powierzchniowy. Jest to ilość adsorbatu (zwykle na jednostkę powierzchni lub jednostkę masy adsorbentu), która $\mathrm{W}$ wyniku adsorpcji przemieściła się $\mathrm{z}$ tzw. "fazy objętościowej" (część układu poza zasięgiem sił adsorpcyjnych) do "fazy powierzchniowej" (w zasięgu sił adsorpcyjnych). "Faza powierzchniowa" często ogranicza się do jednej lub kilku średnic cząsteczek adsorbatu.

Typowe metody pomiaru adsorpcji opierają się na analizie bilansu masy. W przypadku adsorpcji gazów stosuje się najczęściej metody wolumetryczne.

Do opisu stanu równowagi adsorpcyjnej stosuje się najczęściej tzw. równania izoterm adsorpcji. Izotermy opisują charakter zależności zaadsorbowanej ilości adsorbatu od jego ciśnienia lub stężenia, przy zachowaniu stałej temperatury. Spotyka się także izostery (stała ilość zaadsorbowana, zmienna temperatura i ciśnienie) i izobary (stałe ciśnienie adsorbatu, zmienna temperatura i ilość zaadsorbowana).

Poniżej podano izotermy adsorpcji gazów i par z krótką ich charakterystyką:

- Izoterma Henry'ego - nie uwzględnia nasycania powierzchni adsorbentu adsorbatem.
W rzeczywistości należy się spodziewać wyczerpania miejsc, w których może gromadzić się adsorbat.

- Izoterma Langmuira - brak możliwości tworzenia wielowarstwy, stałość energii adsorpcji. Zaadsorbowane cząstki tworzą na powierzchni adsorbentu tzw. monowarstwę cząsteczek oddziaływujących $\mathrm{z}$ miejscami adsorpcyjnymi, a nie oddziaływującymi ze sobą. Prawdopodobieństwo zaadsorbowania/desorpcji zależy od temperatury i wielkości energii adsorpcji. Wraz z ciśnieniem rośnie częstość uderzeń cząsteczek w powierzchnię, a wraz z ilością zaadsorbowanych cząsteczek maleje dostępna powierzchnia.

- Izoterma Freundlicha - charakter eksperymentalny, opisująca dobrze adsorpcję na powierzchniach heterogenicznych (energetycznie niejednorodnych) oraz na adsorbentach mikroporowatych.

- Izoterma Brunauera, Emmetta i Tellera (BET) - to prosty model adsorpcji wielowarstwowej z fazy gazowej. Zakłada się, że cząsteczki adsorbatu adsorbują w sposób zlokalizowany (tzn. cząsteczki nie mogą się przemieszczać po powierzchni, co występuje $\mathrm{w}$ izotermie Langmuira). Na zaadsorbowanych cząsteczkach dzięki oddziaływaniom adsorbatadsorbat (określonym poprzez wielkość ciepła skraplania adsorbatu) mogą adsorbować kolejne cząsteczki adsorbatu. Tak sformułowany model z reguły przewiduje adsorpcję wyższą, niż obserwowana doświadczalnie. W ogólnym przypadku otrzymuje się równanie 3parametrowe (ograniczenie grubości warstwy adsorpcyjnej do n-warstw, np. poprzez ograniczenia wynikające $\mathrm{z}$ wielkości porów lub rozmiaru przestrzeni międzyziarnowych). Po upraszczającym założeniu, że ilość warstw adsorpyjnych nie może być niczym ograniczona, otrzymuje się 2-parametrowe klasyczne równanie BET. Mimo niezbyt realistycznych założeń, dzięki swej prostocie model osiagnął sukces, stając się podstawą analizy powierzchni ciał stałych.

\subsection{Wplyw charakteru powierzchni adsorbentu na adsorpcję}

Wpływ na adsorpcję ma energetyczna niejednorodność powierzchni (np. zróżnicowany skład chemiczny, tzw. grupy powierzchniowe, defekty krystaliczne).

Niejednorodność energetyczną powierzchni adsorbentu uwzględnia się poprzez wykorzystanie tzw. uogólnionego równania całkowego adsorpcji (globalnego całkowego równania adsorpcji): 


$$
\theta_{t}(p)=\int_{E_{\min .}}^{E_{\max }} \chi(E) \theta_{l}(p, E) d E
$$

gdzie:

$\theta_{t}-$ globalne pokrycie powierzchni (średnia dla całej powierzchni), zależne od ciśnienia $p$

$\theta_{l}(p, E)$ - lokalne pokrycie powierzchni, zależne od energii adsorpcji danego miejsca adsorpcyjnego $E$

$\theta(E)$ - normalizowana funkcja rozkładu energii adsorpcji (gęstość prawdopodobieństwa).

Izoterma globalna $\theta_{t}$ (otrzymana jako uśrednienie izotermy lokalnej po różnych typach miejsc adsorpcyjnych) oraz izoterma lokalna $\theta_{l}(p, E)$ (dla określonego typu miejsc adsorpcyjnych) są silnie zależne od temperatury.

Najczęściej stosowane izotermy lokalne to izoterma Langmuira (zlokalizowana monowarstwowa adsorpcja fizyczna na powierzchni homogenicznej, bez oddziaływań bocznych adsorbat-adsorbat) oraz izoterma Fowlera-Guggenheima (adsorpcja z oddziaływaniami niespecyficznymi o charakterze uśrednionego pola, $\mathrm{z}$ oddziaływaniem bocznym adsorbatadsorbat) lub izotermy uwzględniające oddziaływania specyficzne związane z asocjacją (np. izoterma Kisielewa). Często wykorzystuje się też odpowiednie izotermy uwzględniające tworzenie wielu warstw adsorbatu, np. izotermę BET.

$\mathrm{Z}$ reguły zakłada się, że adsorpcja jest adsorpcją zlokalizowaną. W przypadku, gdy energia ruchu termicznego na płaszczyźnie cząsteczek jest duża w porównaniu do bariery potencjału pomiędzy miejscami adsorpcyjnymi i cząsteczki nie są zlokalizowane, wówczas należy wykorzystywać izotermy lokalne opisujące adsorpcję mobilną lub częściowo mobliną, np. izotermy Volmera czy Hilla-deBoera.

Systematyzując, wyróżnia się:

- Izotermy lokalne dla adsorpcji zlokalizowanej:

- Izotermy lokalne bez oddziaływań bocznych (Izoterma Langmuira jako izoterma lokalna, bez oddziaływań bocznych)

- Izotermy lokalne z oddziaływaniami bocznymi(Izoterma Fowlera-Gugenheima, izoterma Kisielewa - zależne od topografii powierzchni adsorbentu)

- Izotermy lokalne uwzględniające tworzenie wielowarstwy (izoterma BET, izoterma Lopez-Gonzaleza i Dietza LGD)

- Izotermy lokalne dla adsorpcji mobilnej:

- Izotermy lokalne bez oddziaływań bocznych (izoterma Volmera)

- Izotermy lokalne z oddziaływaniami bocznymi (izoterma Hilla-deBoera)

\subsection{Struktura porowata}

Istotną okazuje się struktura granicy faz, najczęściej struktura powierzchni stałego adsorbentu, tzw. niejednorodność strukturalna. Analizę jej prowadzi się przy pomocy: metod adsorpcyjnych (pomiar izoterm adsorpcji i analiza metodami t-plot, alfa-s) i metod rentgenostrukturalnych (XRD, SAXS). Pominięto opis wymienionych metod analizy.

Mikropory. Adsorpcja w niewielkich porach, tzw. mikroporach, o średnicach porównywalnych $\mathrm{z}$ rozmiarami cząsteczki adsorbatu $(<2 \mathrm{~nm})$ jest znacznie silniejsza, niż na takiej samej chemicznie powierzchni płaskiej (większa ilość atomów adsorbatu oddziałuje z bliska $\mathrm{z}$ adsorbentem) i najczęściej jest opisywana za pomocą równania DubininaRaduszkiewicza (DR).

Izoterma globalna $\theta_{t}(p)$ oraz izoterma lokalna $\theta_{l}(p, B)$ są silnie zależne od temperatury. Funkcja rozkładu parametru strukturalnego $F(B)$ może również słabo zależeć od temperatury. Jako izotermę lokalną wykorzystuje się przede wszystkim izotermę Dubinina-Raduszkiewicza.

Rozwiązanie równania adsorpcji pozwala na określenie rozkładu parametru strukturalnego i w konsekwencji rozkładu porów adsorbentu. W sposób ogólny opisuje adsorpcję na ciele stałym o dowolnym rozkładzie mikroporów (tzn. strukturalnie niejednorodnym), uwzględniając różnice $\mathrm{w}$ modelu adsorpcji, wynikające $\mathrm{z}$ różnic $\mathrm{w}$ ich kształcie mikroporów, poprzez odpowiedni dobór izotermy lokalnej.

Podstawowym parametrem mikroporów jest objętość wlaściwa - $\mathrm{w}$ przemysłowych zastosowaniach wynosi ok. $0,5 \mathrm{~cm}^{3} / \mathrm{g}$, oraz powierzchnia wlaściwa, która wynosi $1200 \mathrm{~m}^{2} / \mathrm{g}$.

Mezopory. Adsorpcja w porach pośrednich, tzw. mezoporach (średnica $2 \div 50 \mathrm{~nm}$ ) jest również silniejsza, niż na powierzchni płaskiej. Dla ciśnienia adsorbatu niższego od ciśnienia pary nasyconej następuje tzw. kondensacja kapilarna, czyli nagłe, całkowite zapełnienie adsorbatem wszystkich porów o tym samym kształcie i średnicy (ilościowo opisuje ją równanie Kelvina).

Powierzchnia właściwa mezoporów wynosi $10 \div 400 \mathrm{~m}^{2} / \mathrm{g}$. Mezopory pełnią funkcję arterii transportowych, przez które następuje doprowadzenie substancji do mikroporów.

Większe pory (średnica powyżej $50 \mathrm{~nm}$; czasami określana jako ponad $100 \mathrm{~nm}$ ) są nazywane makroporami i adsorpcja $\mathrm{w}$ nich nie różni się znacznie od adsorpcji na powierzchniach płaskich.

\section{Proces osuszania sprężonego powietrza 4.1. Osuszacze adsorpcyjne}

Praktycznym efektem matematycznych rozważań okazał się osuszacz powietrza, ze względu na wykorzystywane zjawiska fizyczne nazwany osuszaczem adsorpcyjnym. 
Osuszacze adsorpcyjne podlegające regeneracji zawierają substancję susząca, która adsorbuje parę wodną występującą w strumieniu powietrza. Wilgoć jest usuwana $\mathrm{z}$ tych substancji $\mathrm{w}$ procesie regeneracji poprzez przedmuchiwanie suchym niesprężonym powietrzem, ogrzewanie (wewnętrzne lub zewnętrzne) lub kombinację obu sposobów.

Osuszacze adsorpcyjne składają się zazwyczaj z dwóch jednakowych kolumn (rys. 3).

Podczas gdy w kolumnie A zachodzi proces suszenia powietrza $\mathrm{z}$ kompresora, w kolumnie $\mathrm{B}$ zachodzi proces regeneracji adsorbentu. W osuszaczach ze zmiennym ciśnieniem (swing, nieogrzewanych) wymaga się, aby powietrze przedmuchujące stanowiło od $10 \%$ do $18 \%$ całkowitego przepływu powietrza. W osuszaczach tego typu można uzyskać powietrze o punkcie rosy od $-40^{\circ} \mathrm{C}$ do $-73^{\circ} \mathrm{C}$.

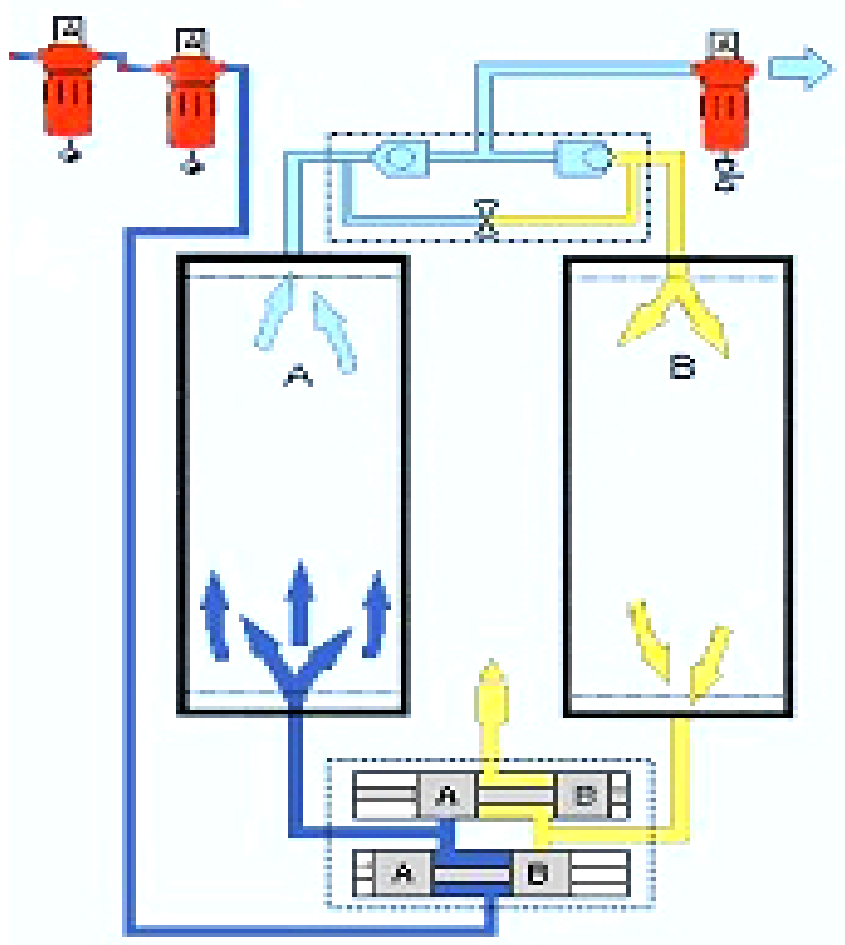

Rys. 3. Schemat poglądowy osuszacza adsorpcyjnego [13]

Sprężone powietrze, które opuszcza sprężarkę, zawiera zanieczyszczenia w postaci ciał stałych oraz kondensatu wodno-olejowego. Te zanieczyszczenia eliminuje z powietrza układ cyklonu i zaworów zabudowanych przed osuszaczem.

Pozostała, zawarta w sprężonym powietrzu, para wodna dociera do osuszacza poprzez płytkę rozdzielająca, zawierającą kombinację zaworów. Przy adsorpcji strumień powietrza przepływa $\mathrm{z}$ dołu do góry poprzez odporny na wodę środek suszący w kolumnie adsorpcyjnej A. Środek suszący kumuluje przenoszoną wilgoć. Czyste i suche sprężone powietrze opuszcza osuszacz adsorpcyjny poprzez płytę głowicy zawierająca kombinację zaworów zwrotnych. Równolegle $\mathrm{z}$ osuszaniem w kolumnie A, w kolumnie B odbywa się regeneracja. Część strumienia osuszonego sprężonego powietrza skierowana jest do kolumny B dzięki dyszy regeneracyjnej. Rozprężone i suche powietrze dla regeneracji przepływa w przeciwną stronę (z góry do dołu) odciągając $\mathrm{z}$ powierzchni środka suszącego zmagazynowaną wilgoć. Powietrze po regeneracji wydostaje się na zewnątrz poprzez zawór wylotowy oraz thumik.

W celu kontynuacji pracy procesy zachodzące $\mathrm{W}$ obu kolumnach A i B ulegaja cyklicznej zamianie. Sterowanie procesem przełączania może być realizowane odpowiednio wyregulowanym przekaźnikiem czasowym. Nowocześniejszym rozwiązaniem jest przekaźnik sterowany informacją o aktualnej wilgotności powietrza, które opuszcza osuszacz. O momencie przełączenia się komory na regenerację decyduje wtedy progowa wartość wilgotności.

Niekiedy dodatkowo instaluje się na wyjściu indykator wilgotności, który stanowi adsorbent zmieniający swoją barwę pod wpływem wzrostu wilgotności. Przebarwienie tego sorbentu informuje eksploatatora o konieczności wymiany granulatu $\mathrm{w}$ obu komorach osuszacza.

Drobne cząsteczki środka suszącego, które przedostały się z powietrzem, zostają wychwycone przez mikrofiltr, który pełni rolę filtra końcowego.

\subsection{Adsorbenty}

Adsorbenty różniące się między sobą strukturą i charakterem chemicznym powierzchni, są pochodzenia węglowego lub nieorganicznego. Otrzymać je można drogą syntezy lub występują naturalnie w przyrodzie. Efektywny adsorbent musi cechować duża objętość i powierzchnia wewnętrzna, co przejawia się wysoce porowata strukturą. Powierzchnia właściwa adsorbentów zmienia się w zakresie $10 \div 3000 \mathrm{~m}^{2} / \mathrm{g}$. W praktyce spotyka się powierzchnie właściwe $300 \div 1200 \mathrm{~m}^{2} / \mathrm{g}$.

Choć wyróżnia się 3 strukturalne klasy adsorbentów (mikroporowate, mezoporowate i makroporowate), to większość adsorbentów przemysłowych ma strukturę mieszaną.

Wśród adsorbentów porowatych wyróżnić można następujące grupy substancji: żele krzemionkowe (silikażele), tlenki glinowe (aluminożele), zeolity syntetyczne i naturalne (zwietrzeliny minerałów bazaltowych i wulkanicznych), sita molekularne oraz węgiel aktywny.

Należy podkreślić, że występują także adsorbenty nieporowate o powierzchni właściwej do $10 \mathrm{~m}^{2} / \mathrm{g}$, o silnie rozdrobnionej strukturze, czy tzw. aerozole krzemionkowe (osiagające setki $\mathrm{m}^{2} / \mathrm{g}$ ).

W osuszaczach powietrza znalazły zastosowanie różnego rodzaju zeolity syntetyczne. Krystaliczne zeolity stanowią grupę szkieletowych krzemianów, konkretnie są to uwodnione krystalicznymi glikokrzemianami metali I i II grupy układu okresowego pierwiastków: sodu, potasu, magnezu, wapnia, strontu i baru. Skład zeolitów przedstawia ogólny wzór tlenowy: 


$$
\mathrm{M}_{2 / n} \mathrm{O} \cdot \mathrm{Al}_{2} \mathrm{O}_{3} \cdot x \mathrm{SiO}_{2} \cdot y \mathrm{H}_{2} \mathrm{O}
$$

gdzie:

$n, x, y$ - współczynniki charakterystyczne dla danego zeolitu.

Sieć przestrzenna zeolitu zawiera liczne kanały i łączące się ze sobą komory. Ze względu na średnicę otworu wejściowego zeolity sklasyfikowano w sposób przedstawiony w tabeli 6 .

\section{Klasyfikacja zeolitów [1]}

Tabela 6

\begin{tabular}{|l|l|l|l|l|l|}
\hline \multicolumn{1}{|c|}{ Klasyfikacja } & \multicolumn{5}{c|}{ Typy zeolitów } \\
\hline Amerykańska & $3 \mathrm{~A}$ & $4 \mathrm{~A}$ & $5 \mathrm{~A}$ & $10 \mathrm{X}$ & $13 \mathrm{X}$ \\
\hline Rosyjska & KA & $\mathrm{NaA}$ & $\mathrm{CaA}$ & $\mathrm{CaX}$ & $\mathrm{NaX}$ \\
\hline $\begin{array}{l}\text { Średnica otworów } \\
\text { wejściowych [nm] }\end{array}$ & 0,3 & 0,4 & 0,5 & 0,8 & 0,9 \\
\hline
\end{tabular}

I tak, dla przykładu, wzór tlenowy dla zeolitu typu A jest następujący:

$$
\mathrm{Na}_{2} \mathrm{O} \cdot \mathrm{Al}_{2} \mathrm{O}_{3} \cdot 2 \mathrm{SiO}_{2} \cdot 4 \mathrm{H}_{2} \mathrm{O}
$$

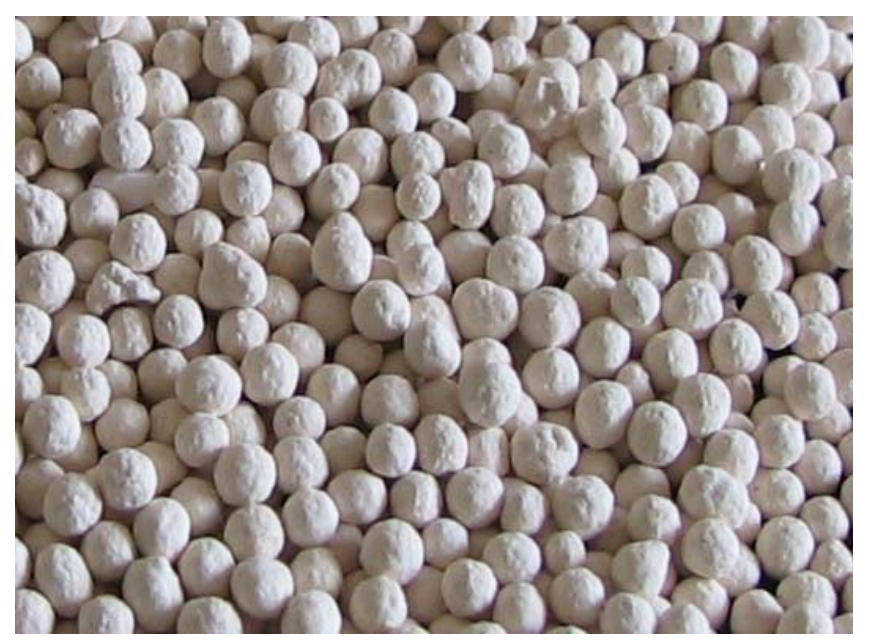

Rys. 4. Sorbet cząsteczkowy typu 4A [13]

Otrzymane syntetycznie zeolity mają zwykle postać proszku. Jednak zastosowanie praktyczne znajdują przede wszystkim zeolity granulowane (rys. 4). W celu otrzymania granulek proszek miesza się z materiałem wiążącym w ilości $15 \div 20 \%$. Lepiszcze musi zapewnić maksymalną wytrzymałość na ścieranie i ułatwiać dyfuzję adsorbatu do wnętrza mikroporów. Lepiszcze stanowi najczęściej bentonit, kaolin lub cement.

Zeolity cechują się specyficznymi własnościami fizycznymi: gęstość $1,9 \div 2,3 \mathrm{~g} / \mathrm{cm}^{3}$, twardość $4 \div 5 \mathrm{w}$ skali Mohsa (wartości znacznie mniejsze od innych glikokrzemianów). Czyste zeolity są bezbarwne. Są to typowe adsorbenty mikroporowate. Ich struktura jest ściśle uporządkowana. Cechuje je duża selektywność adsorpcji oraz właściwości sitowo-molekularne. Zeolity są przede wszystkim unikatowymi środkami osuszającymi.
Adsorpcja pary wodnej na zeolitach ma szereg charakterystycznych cech:

- nawet w obszarze bardzo dużych ciśnień zeolity przejawiają znaczną zdolność adsorpcyjną w stosunku do pary wodnej, o wiele większą niż inne adsorbenty

- adsorpcja pary wodnej w niewielkim stopniu zależy od temperatury

- proces pochłaniania wilgoci odznacza się bardzo dużą szybkością

- zapewniają najwyższy stopień osuszania punkt rosy dochodzi do $-80^{\circ} \mathrm{C}$

- stwarzają mały opór hydrauliczny przepływającemu strumieniowi gazu.

Oprócz osuszania zeolity znalazły także zastosowanie do oczyszczania gazów, magazynowania substancji, rozdzielania mieszanin.

\subsection{Regeneracja adsorbentów}

Regeneracja polega na usunięciu $\mathrm{z}$ adsorbentu zaadsorbowanych wcześniej substancji i przywróceniu mu pierwotnych właściwości w możliwie maksymalnym stopniu. Na proces ten składają się etapy cząstkowe: desorpcja cząsteczek z powierzchni adsorbentu, dyfuzja cząsteczek poprzez układ porów do powierzchni adsorbentu (dyfuzja wewnętrzna), dyfuzja czasteczek od powierzchni adsorbentu do strumienia gazu (dyfuzja zewnętrzna).

Efekty energetyczne regeneracji adsorbentów można zinterpretować w oparciu o schemat wg Kleina przedstawiony na rys. 5 .

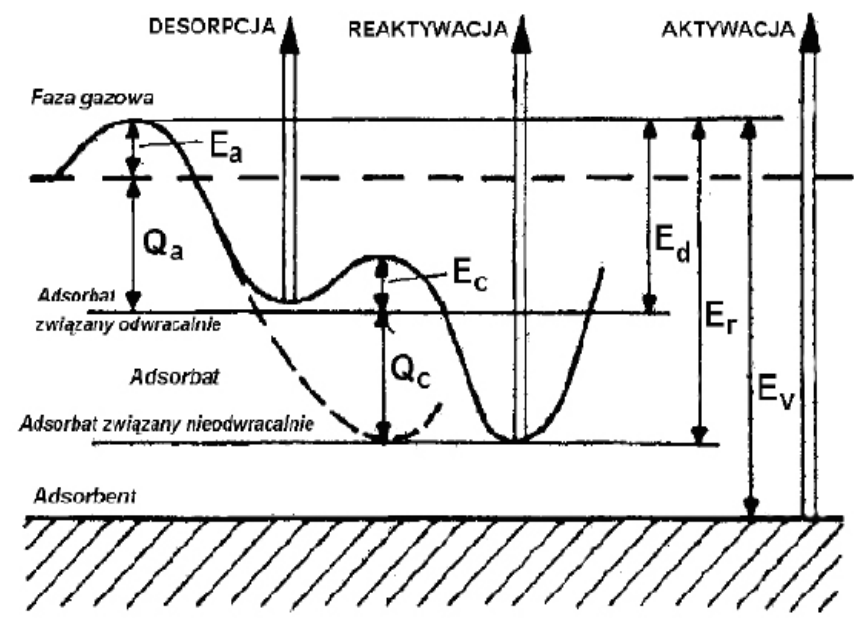

Rys. 5. Efekty energetyczne regeneracji adsorbentu [1]

$E_{v}$ - całkowita energia aktywacji, $E_{r}$ - energia reaktywacji, $E_{d}-$ energia desorpcji, $E_{c}$ - energia aktywacji chemisorpcji, $E_{a}$ - energia aktywacji, $Q_{a}$ - ciepło adsorpcji, $Q_{c}-$ ciepło chemisorpcji

Jeżeli adsorbat jest związany $\mathrm{z}$ adsorbentem $\mathrm{w}$ sposób odwracalny (przypadek adsorpcji fizycznej), energia aktywacji $\left(E_{a}\right)$ jest niższa od energii aktywacji chemisorpcji $\left(E_{c}\right)$. Energia desorpcji $\left(E_{d}\right)$ może zostać dostarczona do układu na różne sposoby, a od jej wielkości zależy wybór metody regeneracji. 
Techniczne procesy adsorpcji można umownie podzielić np. w zależności od stężenia głównego adsorbowanego składnika w mieszaninie: oczyszczanie $2 \div 10 \%_{\text {wag }}$ i rozdzielanie masowe $10 \div 90 \%_{\text {wag }}$ stężenia głównego adsorbowanego składnika. Pierwszy z nich jest charakterystyczny m.in. do odzyskiwania (oczyszczania) z pewnych substancji strumienia powietrza.

W każdej z grup proces może być realizowany $\mathrm{w}$ różnych cyklach adsorpcyjnych, różniących się między sobą sposobem, w jaki nasycony adsorbent poddawany jest regeneracji.

\section{- Cykl zmiennotemperaturowy}

W cyklu zmiennotemperaturowym etap desorpcji prowadzi się w temperaturze wyższej niż etap adsorpcji, wykorzystując różnice $\mathrm{w}$ chłonności sorpcyjnej adsorbentu w różnych temperaturach, a zatem pracuje pomiędzy dwoma izotermami.

Proces realizowany jest zwykle w układzie dwóch równoległych kolumn, w jednej prowadzona jest adsorpcja, druga $\mathrm{w}$ tym czasie poddawana jest regeneracji (rys 6).
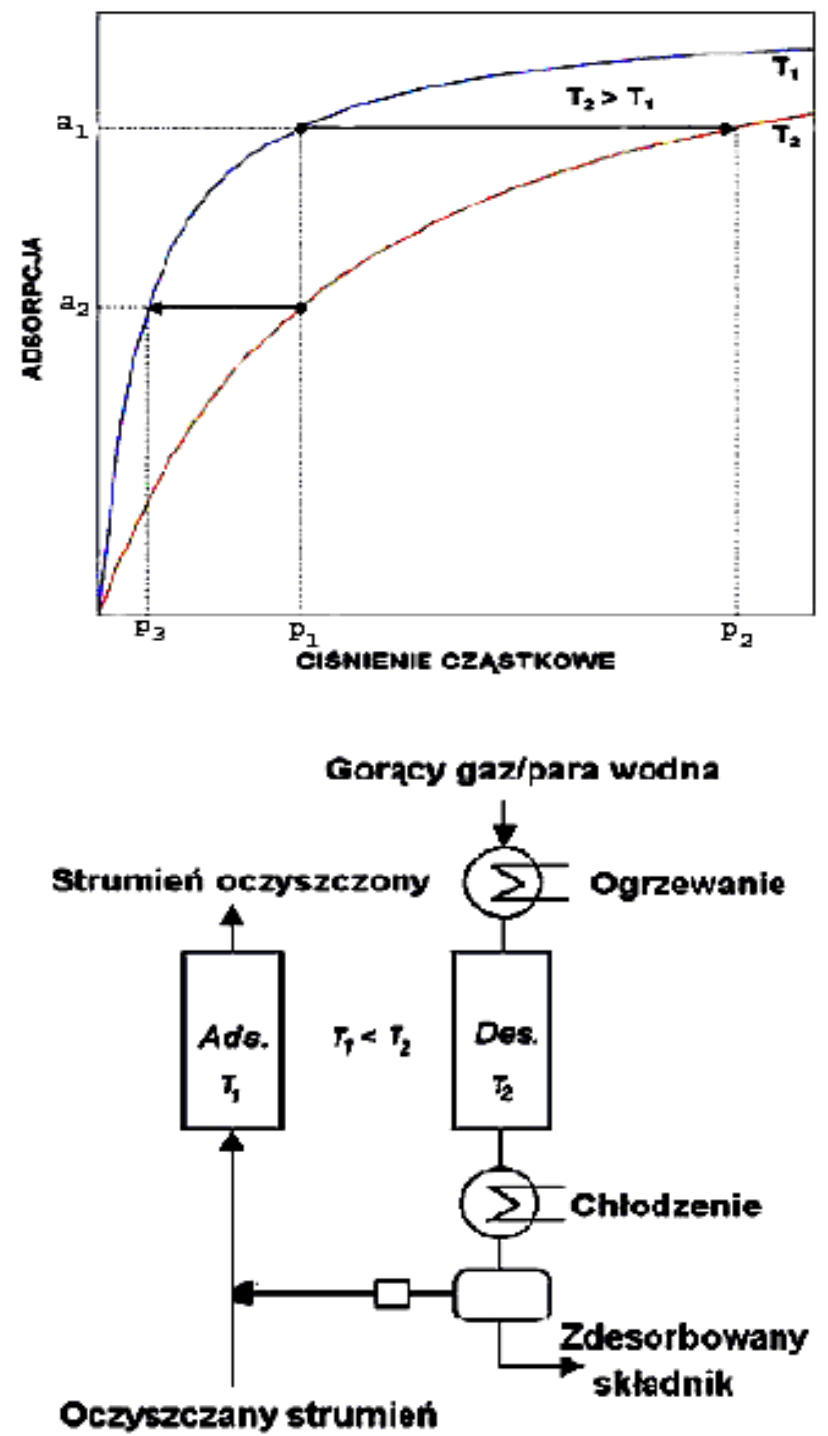

Rys. 6. Schemat cyklu regeneracji zmiennotemperaturowej [1]
Strumień zawierający adsorbowany składnik o ciśnieniu cząstkowym $p_{I}$ przepływa przez złoże adsorbentu $\mathrm{w}$ temperaturze $T_{l}$. Adsorbent $\mathrm{w}$ tym czasie zostaje nasycony do równowagowej wielkości adsorpcji $a_{1}$. Następnie podnosi się temperaturę adsorbentu do $T_{2}$, co sprzyja desorpcji składnika z ziarn adsorbentu i wskutek tego ciśnienie cząstkowe składnika w strumieniu osiaga wartość $p_{2}$. Ogrzewanie adsorbentu można realizować np. przeponowo przez umieszczony w złożu wymiennik ciepła. W praktyce dla usunięcia $\mathrm{z}$ układu zdesorbowanego składnika równocześnie $\mathrm{z}$ ogrzaniem adsorbentu stosuje się przepłukiwanie złoża gorącym gazem lub parą wodna. Na wykresie równowagowym odpowiada to osiagnięciu punktu o współrzędnych $\left(p_{1}, a_{2}\right)$. Ochłodzenie złoża do temperatury $T_{l}$ powoduje przesunięcie równowagi do punktu $\left(p_{3}, a_{2}\right)$. Różnica wielkości adsorpcji w obu temperaturach $\left(a_{1}-a_{2}\right)$ stanowi maksymalną ilość adsorbatu pochłanianego i desorbowanego w cyklu zmiennotemperaturowym.

Czas potrzebny do ogrzania złoża, desorpcji i chłodzenia jest zwykle rzędu kilku do kilkunastu godzin - w tym czasie złoże nie pracuje w cyklu adsorpcji. Sposób ten znajduje zastosowanie zazwyczaj w procesach oczyszczania do usuwania małych ilości adsorbatu, w aparatach o pracy okresowej.

\section{- Cykl ze zmiennym ciśnieniem}

W cyklu tym proces prowadzi się w warunkach praktycznie izotermicznych, pomiędzy dwoma ciśnieniami. Schematyczny obraz procesu w układzie dwukolumnowym przedstawiono na rys. 7.

Adsorpcję prowadzi się przy ciśnieniu wyższym niż desorpcję, a ilość adsorbatu pochłanianego/desorbowanego w jednym cyklu jest równa różnicy wielkości adsorpcji przy dwóch ciśnieniach na izotermie.

Dodatkowa ilość adsorbatu może być jeszcze usunięta ze złoża przez wytworzenie w układzie podciśnienia.

Czas potrzebny do adsorpcji, obniżenia ciśnienia, desorpcji i ponownego podwyższenia ciśnienia jest rzędu sekund do minut, co sprawia, że metoda jest szczególnie atrakcyjna dla procesów objętościowego rozdzielania mieszanin gazowych.

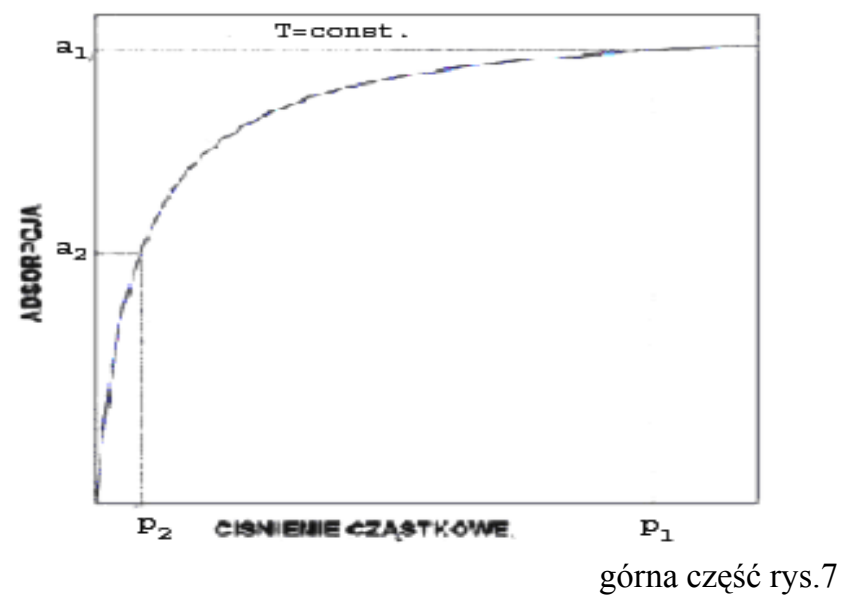




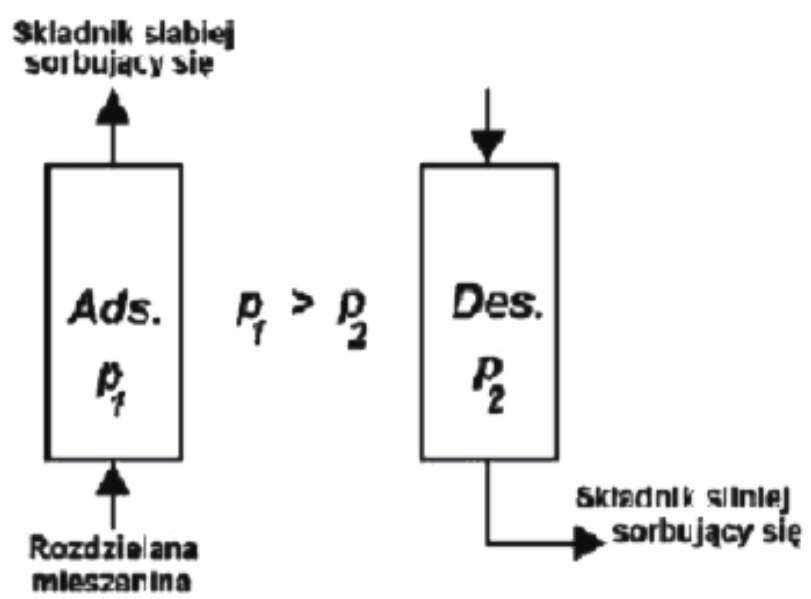

Rys. 7. Schemat cyklu regeneracji ze zmiennym ciśnieniem [1]

- Cykl z przepłukiwaniem adsorbentu gazem obojętnym

W tym cyklu przepuszcza się gaz obojętny, który nie podlega procesowi adsorpcji (rys. 8). Strumień gazu powoduje obniżenie ciśnienia cząstkowego zaadsorbowanego składnika, a zatem sprzyja desorpcji.
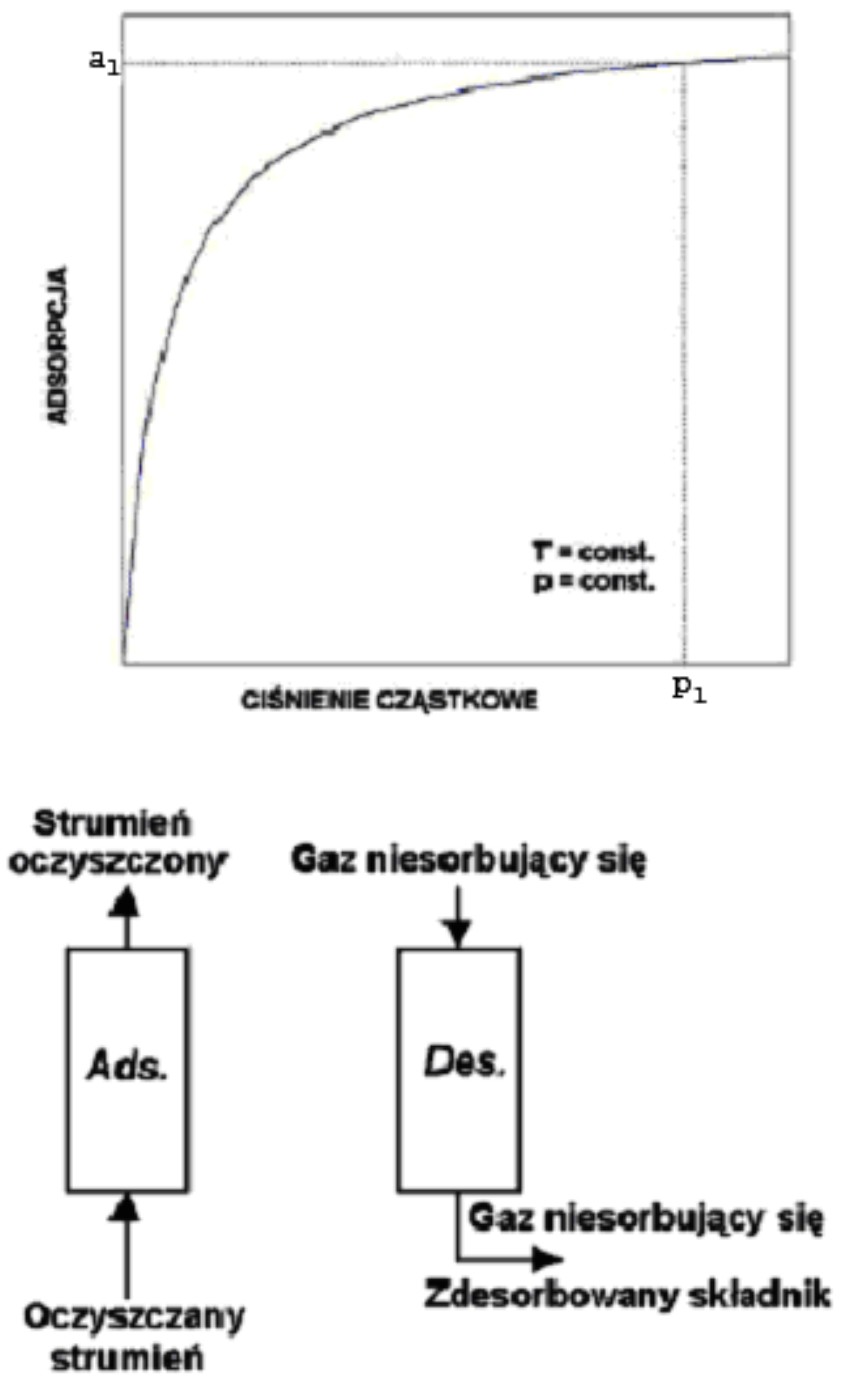

Rys. 8. Schemat cyklu regeneracji gazem obojętnym [1]
Przy podawaniu dostatecznie dużej ilości gazu desorbującego adsorbat może być usunięty praktycznie całkowicie. Taka metoda regeneracji znajduje zastosowanie w przypadkach, gdy adsorbat jest słabo związany $\mathrm{z}$ adsorbentem, $\mathrm{w}$ przeciwnym razie ilość koniecznego do desorpcji gazu może być zbyt duża, a zdesorbowany składnik występuje w stanie silnego rozcieńczenia.

- Cykl z wypieraniem adsorbatu przez składnik lepiej sorbujący

Cykl ten jest podobny do cyklu z przepłukiwaniem adsorbentu gazem obojętnym. Różnica polega jedynie na tym, że do usuwania adsorbatu stosowany jest gaz lub para lepiej sorbująca się od już zaadsorbowanego składnika. Usuwanie adsorbatu ze złoża następuje wskutek obniżenia jego ciśnienia cząstkowego i równoczesną adsorpcję wypierającego medium. Zaletą tego cyklu jest fakt, że efekt cieplny procesu (różnica ciepła pochłanianego i generowanego w adsorbencie) jest bliski zeru, ponieważ ciepło adsorpcji składnika wypierającego jest zwykle bliskie ciepłu adsorpcji głównego adsorbowanego składnika. W wyniku tego złoże adsorbentu pracuje $\mathrm{w}$ warunkach praktycznie izotermicznych.

Oprócz omówionych cykli możliwe są ich kombinacje. Wybór sposobu regeneracji w każdym konkretnym przypadku podyktowany jest względami ekonomicznymi oraz uwarunkowaniami technicznymi.

\subsection{Osuszacze membranowe}

Głównym elementem, odpowiedzialnym za adsorpcję pary wodnej tego typu osuszaczy, jest moduł membranowy, który stanowi wiązka wysokoselekcyjnych lumenizowanych włókien (rys. 9).

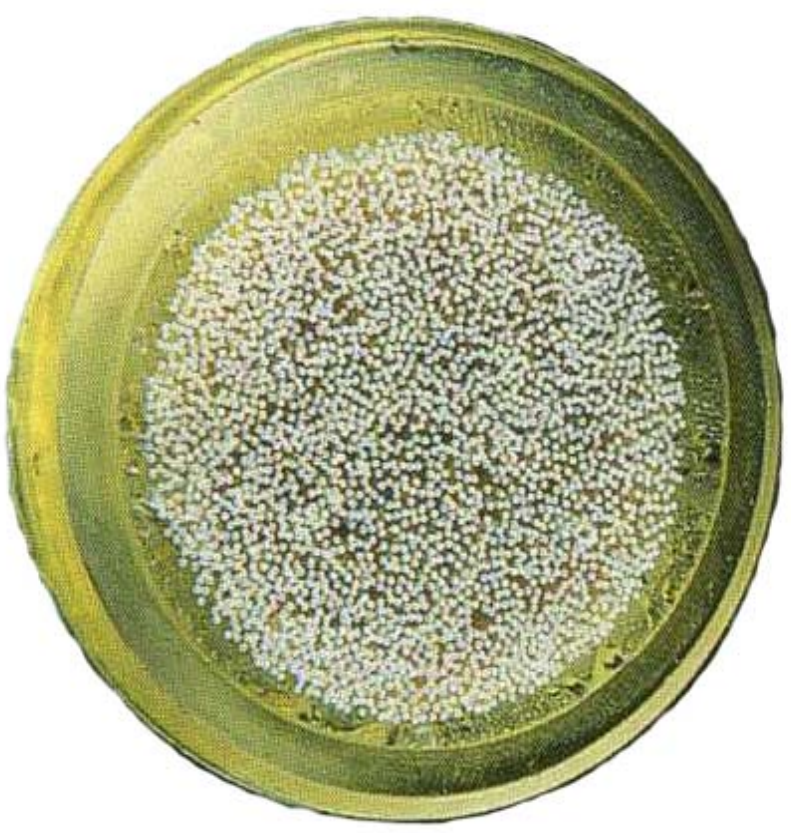

Rys. 9. Moduł membranowy [13] 
Wilgotne, sprężone powietrze doprowadzane jest do króćca wlotowego osuszacza przez filtry (zgrubny i dokładny). Filtry zapewniają ochronę modułu membranowego przed przedostaniem się zanieczyszczeń, aerozoli i oleju. Króciec wlotowy i króciec wylotowy zamocowane są do rury osłaniającej, zawierającej membranę.

Moduł membranowy zawiera ogromną ilość włókien. Osuszanie sprężonego powietrza odbywa się wewnattrz włókien, dzięki specjalnej budowie materiału ścianek membrany. Spiralna struktura włókien membrany pozwala na skrócenie jego długości przy jednoczesnym zachowaniu wydajności osuszania. W ten sposób uzyskuje się większą aktywną powierzchnię membrany na jednostkę powierzchni.

Lumenizowane włókno membrany składa się ze szczególnie porowatej warstwy ochronnej oraz znajdującej się wewnątrz przepuszczającej wodę warstwy rozdzielczej. Cząsteczki pary wodnej są adsorbowane na zewnętrznej powierzchni włókien.

Gdy wilgotne powietrze przepływa przez włókna, to zawarta $\mathrm{w}$ powietrzu para wodna paruje $\mathrm{w}$ warstwie rozdzielczej ze względu na dużą różnice ciśnienia cząstkowego pomiędzy powietrzem przepłukującym, a wilgotnym powietrzem sprężonym. W membranie pojawia się, ze względu na gradient koncentracji, zjawisko dyfuzji pary wodnej zawartej w głównym strumieniu powietrza.

Pory warstwy ochronnej przepuszczaja przez cały czas parę wodna, nawet wtedy, gdy zawarta w powietrzu wilgoć ma kondensować w module lub na włóknach.

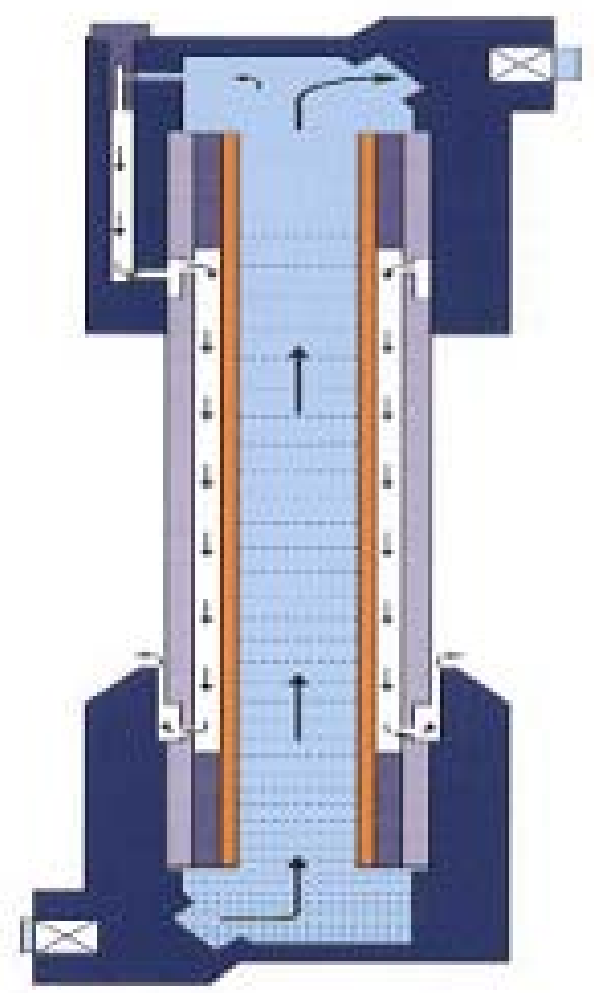

Rys. 10. Schemat budowy osuszacza membranowego [13]
Do końcówki wylotowej dopływa tylko suche powietrze. Adsorpcja wilgoci na włóknach membrany odbywa się bez względu na wielkość strumienia powietrza, a więc $\mathrm{w}$ zakresie od 0 do $100 \%$ przepływu nominalnego. Osuszanie $\mathrm{w}$ ten sposób sprężonego powietrza odbywa się w sposób ciagły w czasie przepływu przez osuszacz (rys. 10).

Suche powietrze jest kierowane $\mathrm{z}$ osuszacza membranowego przez króciec wylotowy. Część powietrza jest kierowana przez zawór regeneracyjny wstecz, w przeciwprądzie wewnątrz rury osłonowej między włóknami.

Niezbędne do osuszania powietrze płuczące stanowi ok. $15 \%$ osuszonego strumienia. Jest stale rozwidlane w strefie wylotowej elementów membrany i, przy zastosowaniu dyszy, rozprężane do ciśnienia atmosferycznego. Wynikająca $\mathrm{z}$ tego większa objętość powietrza zwiększa jego zdolność do pobierania pary wodnej. Dzięki rozprężaniu powietrze płuczące jest znacznie bardziej suche, gdyż zawarta w sprężonym powietrzu wilgoć rozprowadzana jest w dużej objętości. Suche powietrze płuczące przepływa przez zewnętrzną stronę włókien membrany celem "zdmuchnięcia" cząsteczek wody zatrzymanych na zewnętrznych ściankach poszczególnych włókien membrany. Wilgotne powietrze płuczące wydostaje się do otoczenia.

W tym typie osuszacza następuje obniżenie ciśnieniowego punktu rosy zawsze o stałą wartość. Zatem np. sezonowe wahania temperatury powietrza zasysanego przez sprężarkę z otoczenia, nie powodują nigdy pojawienia się kondensacji w rurociagu za osuszaczem.

Osuszacz membranowy nie posiada ruchomych elementów, nie ma więc części zużywających się i nie wymaga serwisowania, zachowując przy tym długą żywotność.

Osuszacz membranowy nie wymaga zewnętrznego źródła zasilania. Dlatego może być z powodzeniem stosowany w warunkach terenowych.

Podsumowując, osuszanie powietrza w osuszaczu membranowym przebiega następująco:

- sprężone powietrze przepływa przez rure rdzeniową $\mathrm{i}$ w obszarze podstawy jest przekierowane do elementów membranowych

- osuszanie odbywa się w module membranowym, stanowiącym wysokoselekcyjne lumenizowane włókna

- powietrze pluczące jest stale rozwidlane w strefie wylotowej elementów membrany i przy zastosowaniu dyszy rozprężane do ciśnienia atmosferycznego; suche powietrze płuczące przepływa przez zewnętrzną stronę włókien membrany

- dwa strumienie powietrza o różnej zawartości wilgoci, oddzielone jedynie ścianą membrany, przepływają przez moduł membranowy $\mathrm{w}$ 
przeciwnych kierunkach; w membranach przepływa wilgotne sprężone powietrze, a na zewnątrz powietrze płuczące; $\mathrm{z}$ powodu odmiennej zawartość wilgoci, wilgoć ze sprężonego powietrza przenika do powietrza płuczącego

- osuszone sprężone powietrze wydostaje się z elementu membranowego

- wilgotne powietrze płuczące wydostaje się do otoczenia .

\section{Podsumowanie}

W eksploatacji pojazdów trakcyjnych sprężone powietrze o określonych parametrach technicznych oraz poziomie czystości jest niezbędne.

Sprawność zamontowanych w układach pneumatycznych pojazdów trakcyjnych urządzeń i aparatury, w dużej mierze zależy od czystości doprowadzanego powietrza.

$\mathrm{Z}$ trzech podstawowych rodzajów zanieczyszczeń powietrza: pyłu, pary wodnej i oleju, najgroźniejszym dla instalacji jest kondensat wodno-olejowy, głównie z uwagi na możliwość powodowania korozji. Toteż na usunięciu tych zanieczyszczeń skupiały się (i nadal skupiaja) działania producentów sprężarek i konstruktorów urządzeń oraz układów uzdatniania sprężonego powietrza.

Do usuwania pary wodnej stosuje się osuszacze. Do najbardziej rozpowszechnionych w pojazdach trakcyjnych należą osuszacze adsorpcyjne, wykorzystujące zjawisko adsorpcji wilgoci. Nieco inne zjawisko (przenikania przez ścianki włókna i oddzielania się pary wodnej $\mathrm{z}$ powietrza) występuje $\mathrm{w}$ osuszaczach membranowych, coraz częściej znajdujących zastosowanie $\mathrm{w}$ pojazdach trakcyjnych, głównie $\mathrm{z}$ powodu małych gabarytów.

W obydwu rodzajach osuszaczy nastepuje regeneracja kosztem $10 \div 15 \%$ straty powietrza. Także obydwa rodzaje należy chronić od wpływu oleju i aerozoli w doprowadzanym do osuszacza sprężonym powietrzu, gdyż prowadzi to do utraty właściwości osuszających. Zanieczyszczenie osuszaczy adsorpcyjnych wymaga wymiany wkładu tj. sorbentu, natomiast osuszaczy membranowych wymiany całego osuszacza. Toteż przed osuszaczami zawsze zamontowuje się przynajmniej jeden, a najczęściej dwa filtry, usuwające drobiny oleju.
Ciagle podejmowane są nowe działania udoskonalające układy uzdatniania sprężonego powietrza. Poszukiwane są nowe rozwiązania urządzeń i sposoby oczyszczania sprężonego powietrza, tańsze, o łatwej obsłudze, a jednocześnie zapewniające niezawodność i dużą skuteczność uzdatniania w trudnych warunkach eksploatacji pojazdów trakcyjnych.

\section{Literatura}

[1] Czepirski L.: Zastosowanie sorbentów, AGH, Kraków 2004.

[2] Komorowska-Czepirska E.: Podstawy technologii sorbentów, AGH, Kraków 2004.

[3] PN-ISO 8573-1:1995 Sprężone powietrze ogólnego stosowania. Zanieczyszczenia i klasy czystości.

[4] PN-ISO 8573-3:2001 Sprężone powietrze Część 3: Metody badań stosowane do pomiaru wilgotności

[5] ISO 8573-1:2001 Compressed air - Part 1: Contaminants and purity classes

[6] ISO 8573-2:2007 Compressed air-Part 2: Test methods for oil aerosol content

[7] ISO 8573-4:2001 Compressed air-Part 4: Test methods for solid particle content

[8] ISO 8573-5:2001 Compressed air-Part 5: Test methods for oil vapour and organic solvent content

[9] ISO 8573-6:2003 Compressed air-Part 6: Test methods for gaseous contaminant content

[10] ISO 8573-7:2003 Compressed air-Part 7: Test method for viable microbiological contaminant content

[11] ISO 8573-8:2004 Compressed air-Part 8: Test methods for solid particle content by mass concentration

[12] ISO 8573-9:2004 Compressed air - Part 9: Test methods for liquid water content

[13] Materiaty promocyjne firm: Atlas Copco, domnick hunter, Donaldson, IZCh Soda Matwy, Kaeser, MZT Hepos. 